\title{
Detailed Fault Structure of the 2000 Western Tottori, Japan, Earthquake Sequence
}

\author{
by Eiichi Fukuyama, William L. Ellsworth, Felix Waldhauser, and Atsuki Kubo
}

\begin{abstract}
We investigate the faulting process of the aftershock region of the 2000 western Tottori earthquake $\left(M_{\mathrm{w}} 6.6\right)$ by combining aftershock hypocenters and moment tensor solutions. Aftershock locations were precisely determined by the double difference method using $P$ - and $S$-phase arrival data of the Japan Meteorological Agency unified catalog. By combining the relocated hypocenters and moment tensor solutions of aftershocks by broadband waveform inversion of FREESIA (F-net), we successfully resolved very detailed fault structures activated by the mainshock. The estimated fault model resolves 15 individual fault segments that are consistent with both aftershock distribution and focal mechanism solutions. Rupture in the mainshock was principally confined to the three fault elements in the southern half of the zone, which is also where the earliest aftershocks concentrate. With time, the northern part of the zone becomes activated, which is also reflected in the postseismic deformation field. From the stress tensor analysis of aftershock focal mechanisms, we found a rather uniform stress field in the aftershock region, although fault strikes were scattered. The maximum stress direction is $\mathrm{N} 107^{\circ} \mathrm{E}$, which is consistent with the tectonic stress field in this region. In the northern part of the fault, where no slip occurred during the mainshock but postseismic slip was observed, the maximum stress direction of $\mathrm{N} 130^{\circ} \mathrm{E}$ was possible as an alternative solution of stress tensor inversion.
\end{abstract}

\section{Introduction}

On 6 October 2000 at 04:30 UTC, the western Tottori earthquake $\left(M_{\mathrm{w}} 6.6\right)$ occurred in southwestern Japan, where very few large earthquakes have occurred since the 1943 Tottori earthquake of $M 7.4$ (Kanamori, 1972) (Fig. 1).

Within the 15 years before the 2000 western Tottori earthquake, background seismicity covered the whole aftershock region of the 2000 western Tottori earthquake and several $M 5$ earthquakes were observed on the mainshock fault of the 2000 western Tottori earthquake (southern part of the aftershock region) (Shibutani et al., 2002). At that time, since the seismic observation network was sparse, they could not obtain the precise geometry of the fault structure in this region. But from the background seismicity, a very vague image of the fault could be obtained before the mainshock. Their result showed that in the southern part of the aftershock region of the western Tottori earthquake, a fault existed before the mainshock but in the northern part, there was no information about the geometry of the fault before the mainshock.

Moreover, Yagi and Kikuchi (2000) and Iwata and Sekiguchi (2001) analyzed the rupture process of the 2000 western Tottori earthquake, and they found that slip occurred only in the southern part of the aftershock region. Sagiya et al. (2002) reported from the analysis of Global Positioning System (GPS) data that the postseismic slip occurred in the northern part of the aftershock region where little slip occurred during the mainshock.

In the western Tottori region, northwest-southeast tectonic loading is dominant (Tsukahara and Kobayashi, 1991) due to the subduction of both the Pacific and Philippine sea plates beneath the Eurasia plate. This is the typical stress environment in the southwest of Japan (Ichikawa, 1971). Due to this driving stress, north-south-or east-west-trending strike-slip faults are commonly observed (Research Group for Active Faults of Japan, 1991).

The western Tottori earthquake and its aftershocks occurred within the recently developed nationwide seismic network. High-quality seismic data were available from the microearthquake networks operated by Hi-net, the Japan Meteorological Agency (JMA), and universities. Broadband waveforms from the FREESIA (now called F-net) broadband seismic network and strong motion waveforms from the K-net and Kik-net are also available. JMA routinely processes the microearthquake data from Hi-net, the university group network, and its own network (Japan Meteorological Agency, 2001). JMA produced the unified data set of phase 
arrival times of the Tottori mainshock and its aftershocks that we used in this study. The National Research Institute for Earth Science and Disaster Prevention (NIED) routinely estimates the seismic moment tensors whose JMA magnitudes are greater than 3.5 using the FREESIA network (Fukuyama et al., 1998, 2001a; Kubo et al., 2002).

A new high-resolution hypocenter relocation technique has recently been developed by Waldhauser and Ellsworth (2000). This technique minimizes the residuals between observed and calculated travel time differences (or double differences [DDs]) for pairs of nearby earthquakes. By forming differences in this manner, the common mode travel time errors are canceled, making the computation insensitive to the assumed velocity structure. We have applied this method to the 2000 western Tottori earthquake and its aftershocks.

In this article, in order to reveal the detailed fault structure in the region of the 2000 western Tottori earthquake, we first relocated its aftershocks using the DD method. Then, we compared the fault structure revealed by the relocated seismicity with the moment tensors obtained from broadband seismic waveforms of the corresponding events. We construct a fault model of the 2000 western Tottori earthquake region based on the relocated aftershock hypocenters and moment tensor solutions. Finally we estimate the stress field using stress tensor inversion and investigate its compatibility with the fault geometry.

\section{Relocation of Aftershock Sequence}

JMA gathers all the data streams from the microearthquake stations of Hi-net, several university networks, and its own network and routinely reads the $P$ - and $S$-wave arrivals to determine the hypocenters (Japan Meteorological Agency, 2001). We used this arrival time data for earthquakes occurring from 6 October to 17 November 2000, in the region between $35.00^{\circ}$ and $35.50^{\circ} \mathrm{N}, 133.00^{\circ}$ and $133.55^{\circ} \mathrm{E}$. In total, there are about 9200 events in the JMA unified data set, and we successfully relocated about 8500 using the DD method.

To relocate the earthquakes with "hypo DD" (a program for the DD method; Waldhauser and Ellsworth, 2000), we used stations within an epicentral distance of $120 \mathrm{~km}$ (Fig. 1) in order to exclude the Pn arrivals. We discarded events with fewer than eight readings. We used a velocity structure with four layers, as shown in Table 1 . The $S$-wave velocity is assumed to be $1 / \sqrt{3}$ of the $P$-wave speed.

We also tested the velocity model used for routine location at the Disaster Prevention Research Institute, Kyoto University (T. Shibutani, personal comm. 2000), which also consists of four layers (Table 1). The main difference between the models is the velocity in the shallow parts. However, there are no distinct differences in the seismicity pattern. This implies that the DD method is robust with respect to the uncertainties in the velocity structure. We prefer the primary model because fewer events were pushed above the

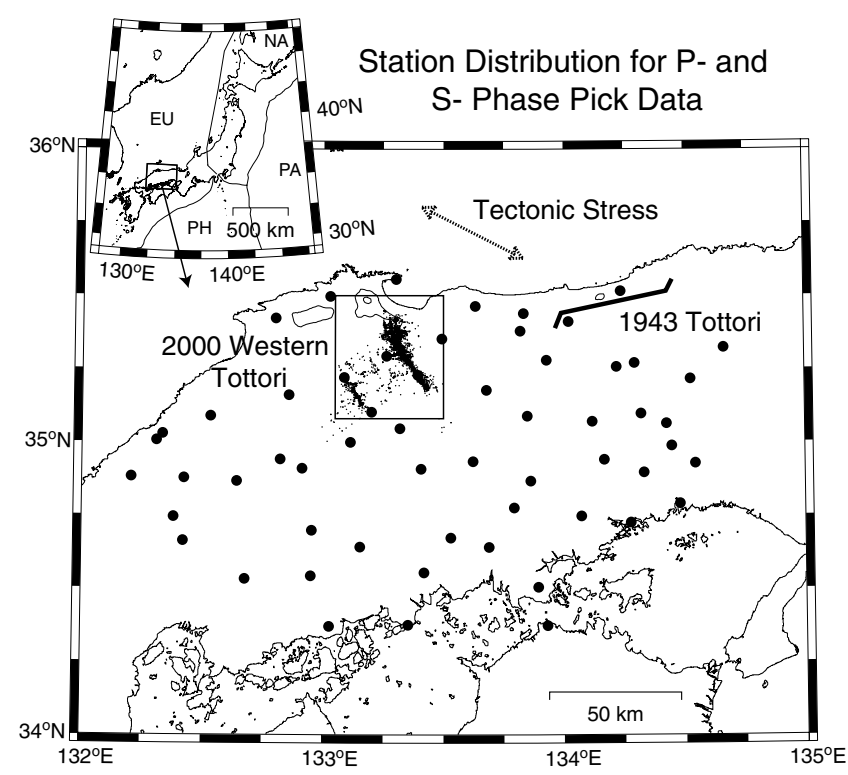

Figure 1. Station distribution of high-gain microseismic network in western Honshu, Japan, used for the relocation. Stations belong to either Hi-net, university network, or the JMA network. The epicentral distribution of the 2000 western Tottori aftershocks and fault trace of the 1943 Tottori earthquakes are also shown. In upper left panel, the configuration of the plates in this region is shown. EU, Eurasian plate; NA, North American plate; PA, Pacific plate; PH, Philippine Sea plate.

Table 1

Velocity Structure

\begin{tabular}{rcrcc}
\hline \multicolumn{2}{c}{ This Study } & & \multicolumn{2}{c}{ Kyoto University } \\
\cline { 5 - 5 } $\begin{array}{c}\text { Depth } \\
(\mathrm{km})\end{array}$ & $\begin{array}{c}P \text {-Wave Velocity } \\
(\mathrm{km} / \mathrm{sec})\end{array}$ & & $\begin{array}{c}\text { Depth } \\
(\mathrm{km})\end{array}$ & $\begin{array}{c}P \text {-Wave Velocity } \\
(\mathrm{km} / \mathrm{sec})\end{array}$ \\
\hline 0.0 & 3.0 & 0.0 & 5.5 \\
1.0 & 4.0 & 2.0 & 6.05 \\
3.0 & 6.0 & 16.0 & 6.6 \\
30.0 & 8.0 & 38.0 & 8.0 \\
\hline
\end{tabular}

model surface, indicating that low velocity near the surface is more appropriate in this case.

Included among the unrelocated earthquakes are fewer than 10 M 3-4 earthquakes that occurred within 1/2 hour of the mainshock. Relocation failed because of an insuffcient number of readings created by their overlapping waveforms. All other unrelocated aftershocks are all $M 2$ or smaller earthquakes. The percentages of unrelocated events for greater than and less than $M 3.0$ events are $2.1 \%$ and $6.6 \%$, respectively. Thus we could successfully relocate most of the important aftershocks.

In Figure 2, the original JMA hypocenters from the unified catalog and the result of the DD relocation are shown. Many fine fault structures that are suggested in the JMA hypocenters can be easily recognized in the DD relocations. In the gross view, two major fault trends are evident. One 
(a) JMA Hypocenters

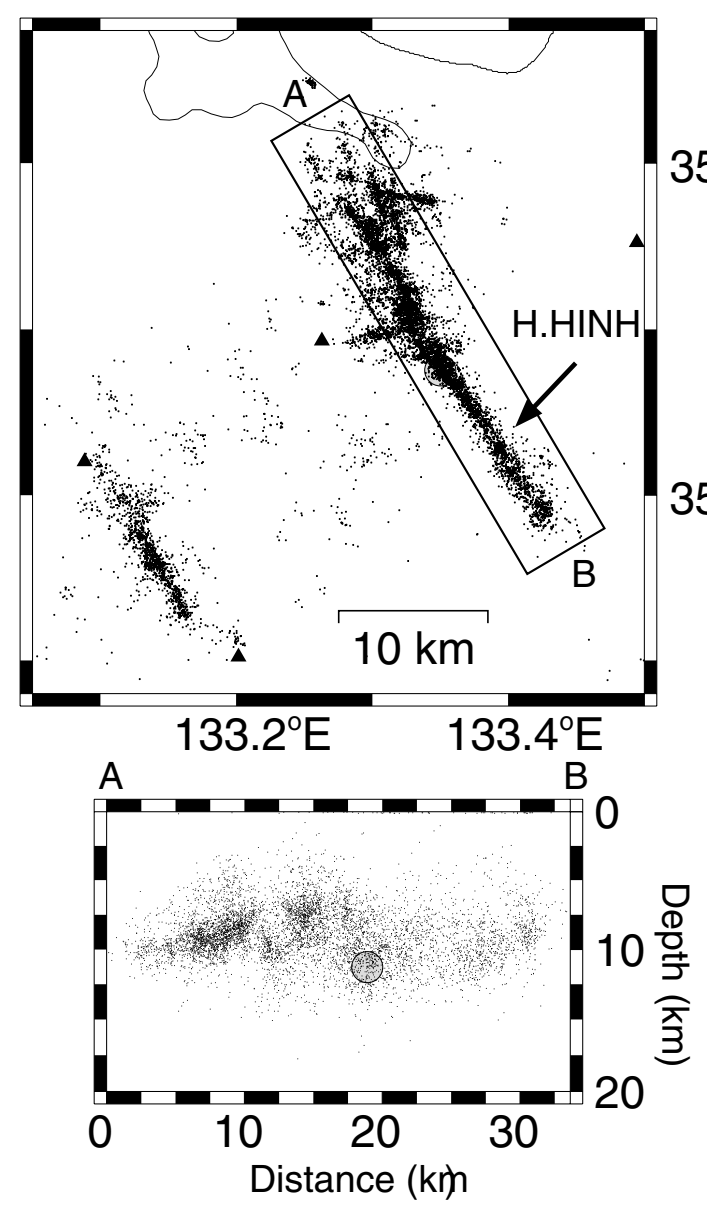

(b) Relocated Hypocenters

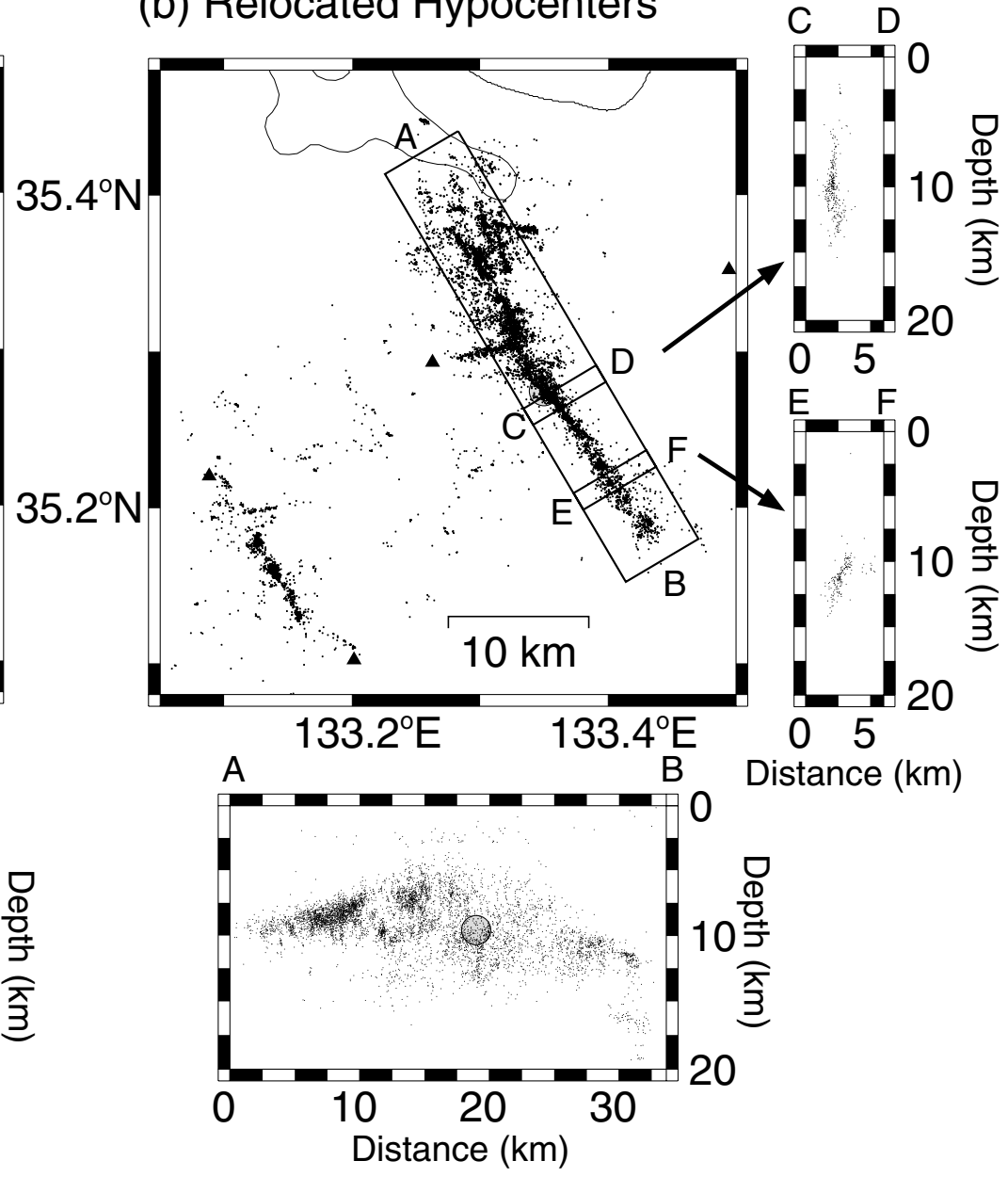

Figure 2. (a) Original distribution of aftershocks estimated by JMA. (b) Distribution of aftershocks relocated by the double difference method. All the earthquakes are plotted with a fixed scale in order to enhance the lineament of the fault trace. The gray circle shows the mainshock hypocenter. Triangles indicate the station locations. Station H.HINH was used to examine the depths of earthquakes. The $\mathrm{AB}$ box in both figures shows the longitudinal cross section of hypocenters. The $\mathrm{CD}$ and $\mathrm{EF}$ cross sections are also shown for relocated hypocenters.

trends $\mathrm{N} 145^{\circ} \mathrm{E}$, which is consistent with the mainshock fault direction. The other is almost north-south $\left(\mathrm{N} 170^{\circ} \mathrm{E}\right)$ in trend, which can be seen in the northern part. It should also be noted that there are conjugate faults for both groups, the western branch and northern fault group. These two lineaments $\left(\mathrm{N} 145^{\circ} \mathrm{E}\right.$ and $\left.\mathrm{N} 170^{\circ} \mathrm{E}\right)$ might suggest a pre-existing fault system at depth $8-10 \mathrm{~km}$.

In Figure 2, a longitudinal cross section of relocated hypocenters is shown. Aftershocks in the southern region (12-30 km in distance in Fig. 2), where slip occurred during the mainshock (Yagi and Kikuchi, 2000; Iwata and Sekiguchi, 2001), are distributed from 2 to $15 \mathrm{~km}$ in depth; however, in the northern part (0-12 km in distance in Fig. 2) where little if any slip occurred during the mainshock, aftershocks are distributed in a very narrow depth range. Toward the southern end of the zone, the fault plane develops a westward dip (Fig. 2).
The sparse geometry of the permanent station network limits our ability to determine focal depths, particularly for the shallowest event. Only two permanent stations are located close to the main body of the aftershock zone, and none atop the complex northern end of the zone. Consequently, our depths in this region are poorly constrained. Focal depths estimated using more than 60 temporary stations installed just above the focal region by the Joint Group for Dense Aftershock Observation of the 2000 Tottori-ken Seibu Earthquake (2001) were reported to be as shallow as $2 \mathrm{~km}$ in the northern part. We believe that their focal depths should be more accurate than ours. Fortunately, the vast majority of the structures observed in the northern part of the zone are vertical strike-slip faults, and thus the lack of absolute depth control little affects their interpretation.

In the southern part of the zone, one permanent station sits just above the fault (H.HINH; see Fig. 2). We can ex- 
amine the depth of earthquakes occurring beneath this station using $S$ - $P$ times. Figure 3 shows the relation between estimated depths and observed $S$ - $P$ times for earthquakes occurring within the epicentral distance of $2 \mathrm{~km}$ from this station. There are some earthquakes that appear to be systematically too deep, but others agree with the observed $S-P$ interval. In this figure, $S-P$ times in the range from 0.4 to $1.8 \mathrm{sec}$ correspond to the depth interval from 3.2 to 14.8 $\mathrm{km}$, assuming that the average $V_{\mathrm{p}}=6 \mathrm{~km} / \mathrm{sec}$ and all earthquakes occur beneath the station (i.e., $\Delta=0 \mathrm{~km}$ ). The depth range of the relocation is $4-15 \mathrm{~km}$, which is consistent with the estimates using $S$ - $P$ times. These depths are also consistent with the depth range of the rupture during the mainshock ( 2 and $15 \mathrm{~km}$ ) estimated by waveform inversion of nearfield accerelograms (Iwata and Sekiguchi, 2001).

In Figure 4, the temporal development of the cumulative aftershock distribution is shown. Within 15 min of the mainshock, the aftershocks concentrate along the southern part, where the slip during the mainshock is estimated to occur (e.g., Yagi and Kikuchi, 2000; Iwata and Sekiguchi, 2001). By 60 min after the mainshock, activity appears throughout the entire extent of the aftershock region. As time progresses, activity fills in the fault structures.

On 8 October at 13:17, the largest aftershock $\left(M_{\mathrm{w}} 5.1\right)$ occurred about $20 \mathrm{~km}$ west of the mainshock region. This event was followed by its own aftershocks. With additional passage of time, the structures within the main zone densified and widened, which might suggest that the aftershock activity expanded from the mainshock fault surface to the entire fault zone. Also, several new alignments of aftershocks were recognized inside the aftershock region.

As stated before, there are about 10 relatively large earthquakes $(M>2)$ that occurred within $30 \mathrm{~min}$ after the mainshock and could not be relocated, but other unrelocated earthquakes are all very small earthquakes $(M<2)$. Thus

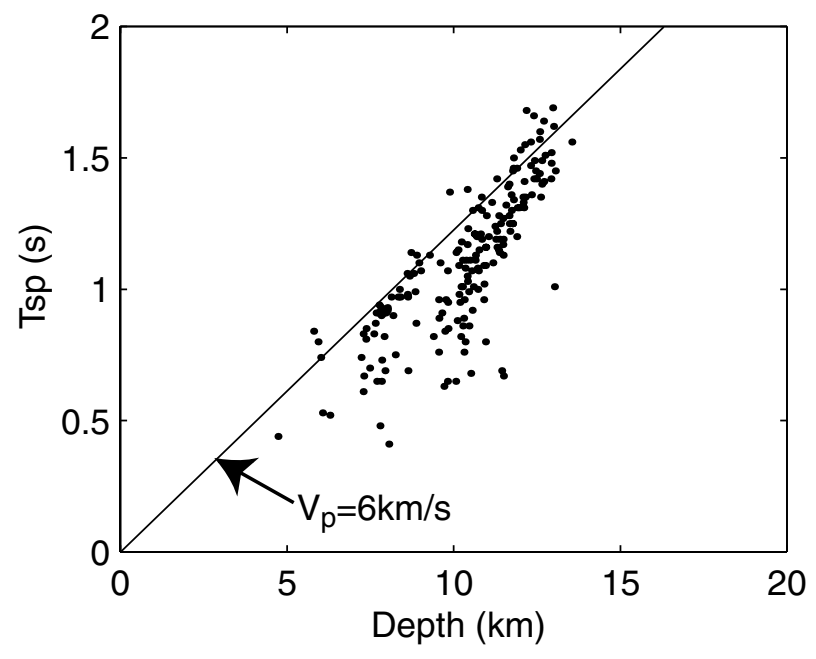

Figure 3. Correlation plot between $S$ - $P$ times and their depths of aftershocks occurring within $3 \mathrm{~km}$ from station H.HINH shown in Figure 2. while the first snapshot in Figure 4 is missing about 10 detected earthquakes, the other snapshots will not change significantly since the total number of unrelocated earthquakes is only $6.4 \%$.

\section{Fault Model by Aftershocks and Moment Tensors}

In Figure 5, strike directions and moment tensor solutions for $M \geq 3.5$ aftershocks are displayed together with all relocated hypocenters. All focal mechanism parameters are listed in Table 2. The strike directions are estimated from the moment tensor analysis using broadband seismic waveforms (Fukuyama et al., 1998, 2001a). The details of the procedure can also be found in Fukuyama and Dreger (2000), Fukuyama et al. (2001b), and Kubo et al. (2002). Among the two possible fault planes in the moment tensor solution, the fault plane was chosen in the following way. First, the direction close to that of the mainshock rupture $\left(\mathrm{N} 150^{\circ} \mathrm{E}\right)$ is chosen. The provisional plane is then compared to the fault trend of the DD hypocenters, and obvious disagreements are manually switched to the auxiliary plane.

According to Kubo et al. (2002), errors in principal axis directions are less than $15^{\circ}$ in the NIED seismic moment tensor catalog. This error estimate is based on the comparison between NIED moment tensors, Harvard Centrold Moment Tensor, and JMA focal mechanism catalog. In the Tottori region, since observational conditions are more favorable than those of offshore earthquakes, this $15^{\circ}$ error might be an upper bound.

One can see in Figure 5 the excellent agreement between relocated seismicity and fault strike directions estimated by the moment tensors. Taking into consideration the estimation errors of principal axis directions of moment tensors and fits between strikes from moment tensors and hypocenter distribution, the results suggest that the scattering of the principal axes of moment tensors of aftershocks is caused by a locally complicated fault system.

We have modeled the fault structure based on the relocated aftershocks. By looking at the map view of relocated aftershocks, the strike of each fault was chosen. Then from the cross section perpendicular to the fault strike, the dip angle of each fault was estimated. These selections were done by hand. We did not use a fitting algorithm to obtain the fault plane automatically, because it was diffcult to separate the earthquakes on the fault from off-fault ones. Instead, by using human eyes, we could obtain a robust fault model that convincingly explains the relocated hypocenters. The fault model is shown in Table 3 and Figure 6. We also compared the fault model with the moment tensor solutions in order to check the geometry of each fault. This comparison explicitly assures the validity of the fault-plane selection by hand. Slip directions shown in Table 3 were obtained from the moment tensor solutions.

The obtained fault traces can be classified into two groups of left-lateral faults, $\mathrm{N} 145^{\circ} \mathrm{E}$ (faults $1,2,4,5,6$ ) and $\mathrm{N} 165^{\circ} \mathrm{E}$ (faults $9,12,13$ ). It should be noted that the two 

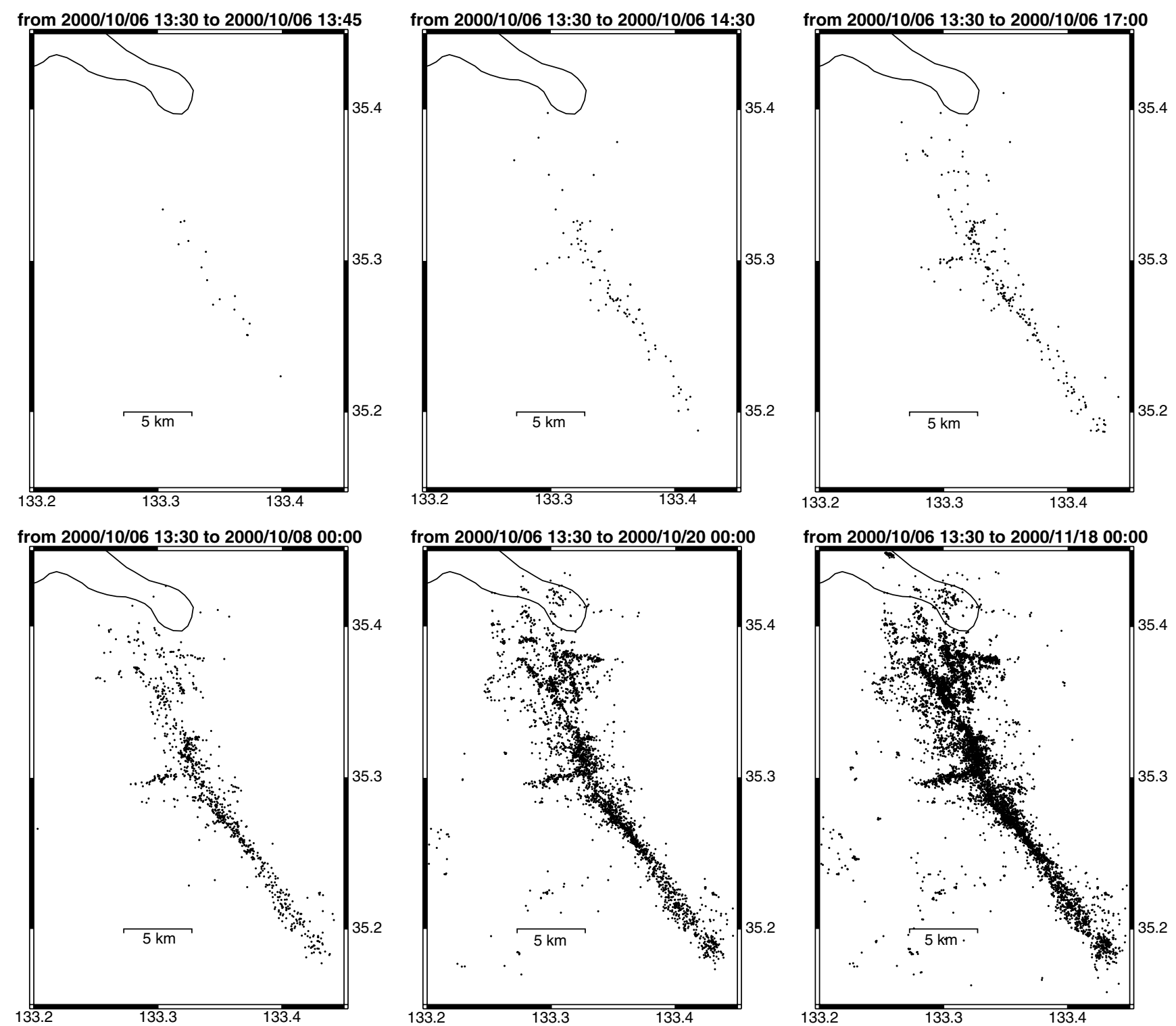

Figure 4. Snapshots of the temporal change of cumulative aftershock distribution. Aftershock activity in the western part is not shown. The time window (JST, UTC +9) is indicated at the top of each panel.

fault groups also have associated conjugate right-lateral faults (fault 3 for the former group and faults 10 and 11 for the latter). This reflects a very complicated deformation field in this region, especially for the northern part of the fault.

\section{Estimated Stress Field}

In order to estimate the stress field, we have conducted stress tensor inversion using $P$ - and $T$ - axis directions of fault-plane solutions obtained from the moment tensor solutions (Fig. 5). We used the code "FMSI" developed by Gephart and Forsyth (1984) and Gephart (1990a,b). FMSI employs the grid search method to find the best-fit stress tensor that explains the fault-plane solution data set. In this computation we used three different weighting schemes: constant, proportional to magnitude, and proportional to variance reduction. We found the result stable for all three different weighting schemes. Here we used the variance reduction weighting scheme because this weighting scheme might reflect the data quality. Following Gephart and Forsyth (1984), we evaluated the $95 \%$ confidence range of the solution as an index of error estimates. The result is shown in Figure 7 and Table 4.

Using all available fault-plane solutions, the azimuths of the $\left(\sigma_{1}, \sigma_{2}, \sigma_{3}\right)$ directions are $\left(107^{\circ}, 330^{\circ}, 200^{\circ}\right)$, respectively, where $\sigma_{1}, \sigma_{2}, \sigma_{3}$ stand for maximum, intermediate, and minimum principal stress, respectively. Compression is positive as conventionally used. $R$, which is defined as $\left(\sigma_{1}-\sigma_{2}\right) /\left(\sigma_{1}-\sigma_{3}\right)$, is 0.60 . We call this solution ALL. 
(a) Fault Strike Distribution from Moment Tensors

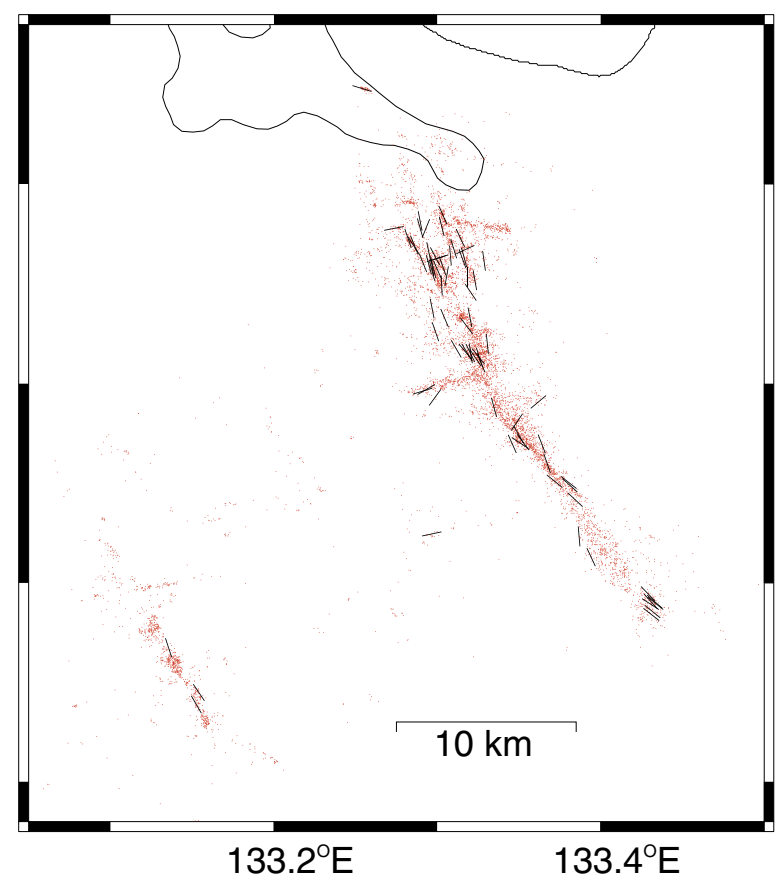

(b) Moment Tensor Solutions (Mw $\geq 3.5$ )

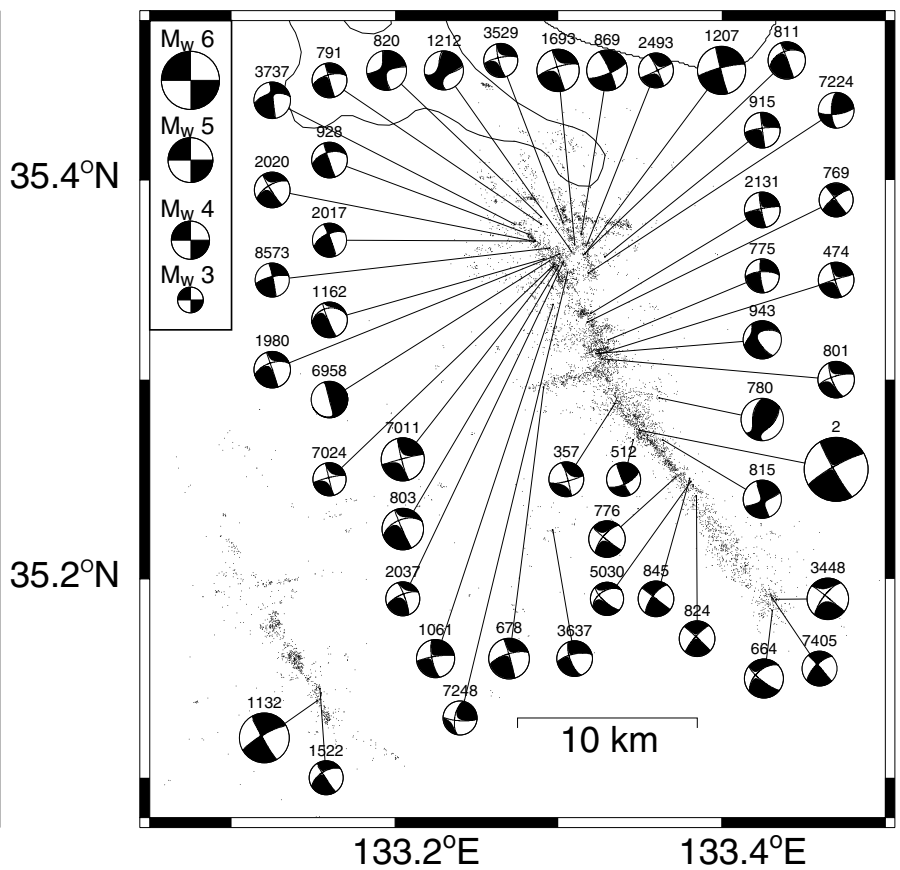

Figure 5. (a) Strike directions derived from the moment tensor analysis plotted together with the relocated aftershock distribution. (b) Estimated moment tensors of aftershocks $\left(M_{\mathrm{w}} \geq 3.5\right)$, plotted with relocated locations. The numbers appearing above each moment tensor correspond to the event ID in Table 2.

The $95 \%$ confidence region is quite small (less than $15^{\circ}$ ). The $\sigma_{1}$ direction obtained here is consistent with the tectonic stress field in this region by Tsukahara and Kobayashi (1991), who compiled focal mechanisms of shallow earthquakes and in situ measurements of stress in southwest Japan. Although fault strikes are scattered, the uniform stress field over the aftershock region seems to be able to explain the variation of fault-plane solutions.

However, as mentioned in the previous section, in the northern part of the aftershock region two conjugated fault pairs (the $\mathrm{N} 145^{\circ} \mathrm{E}$ group and $\mathrm{N} 165^{\circ} \mathrm{E}$ group) are found. Thus we also conducted the stress tensor inversion both for the northern and for the southern part in order to examine if the stress field in the entire region is homogeneous or not. We divided the whole area into two regions: north of $35.33^{\circ} \mathrm{N}$ and south of $35.33^{\circ} \mathrm{N}$ (Fig. 6). In this case, the $M 5.1$ aftershock and its aftershocks occurring in the western part and the mainshock were excluded.

The result is shown in Figure 7 and Table 4. In the southern part, we obtained a similar solution as that used for whole region (we call this solution South). The 95\% confidence region is also very similar to that of ALL. However, in the northern part, the solution (which we call North 1) was rotated about $20^{\circ}$ clockwise with small $R$. The $95 \%$ confidence region was found to be broad compared to that of South.

Since the result in the northern part does not seem to be well constrained by the data, we introduced an additional constraint in $R$. We conducted two inversions assuming either $R<0.4$ or $R \geq 0.4$. For the $R<0.4$ case, we obtained the same solution as North 1 . On the other hand, for the $R \geq 0.4$ case, we obtained the solution with the $\sigma_{1}$ direction of $\mathrm{N} 107^{\circ} \mathrm{E}$ (we call this North 2), which is very similar to ALL and South. The residuals were not so different (Table 4). This result suggests that the stress field in this region can be considered homogeneous. Although the North 1 solution suggested a spatial variation of stress, its $95 \%$ confidence region is broad and a homogeneous solution (North 2 ) is still possible.

Since we obtained the geometry of the fault system (Fig. 6), we could compare the result with that by stress tensor inversion. For the southern part, if we assume that left-lateral faults $1,2,4$ and right-lateral fault 3 are a conjugated pair (Fig. 6 and Table 3), the direction of principal stress axis $\left(\sigma_{1}\right)$ is estimated at $\mathrm{N} 110^{\circ} \mathrm{E}$ using the two conjugate strike directions. Although this is a rough estimate, this value is consistent with the stress tensor inversion result, and we could confirm that stress tensor inversion works quite well. For the northern part, left-lateral faults 9, 12, and 13 and right-lateral fault 10 are assumed to be a conjugated pair (Fig. 6 and Table 3), the principal axis direction becomes $\mathrm{N} 110^{\circ} \mathrm{E}$ as well. This supports the second solution (North 2) of the stress tensor inversion. However, if we assume 9, 12, and 13 as left-lateral faults and 11 as a right-lateral fault, 
Table 2

List of Best-Fit Double-Couple Focal Mechanism Solutions Obtained by the Moment Tensor Analysis

\begin{tabular}{|c|c|c|c|c|c|c|c|c|c|}
\hline Event ID & $\begin{array}{c}\text { Origin Time } \\
\text { (yyyy/mm/dd JST) }\end{array}$ & $\begin{array}{l}\text { Latitude } \\
\left({ }^{\circ} \mathrm{E}\right)\end{array}$ & $\begin{array}{l}\text { Longitude } \\
\left({ }^{\circ} \mathrm{N}\right)\end{array}$ & $\begin{array}{l}\text { Depth } \\
(\mathrm{km})\end{array}$ & $M_{\mathrm{w}}$ & $\begin{array}{c}M_{0} \\
(\mathrm{Nm})\end{array}$ & $\begin{array}{l}\text { Strike } \\
\left({ }^{\circ}\right)\end{array}$ & $\begin{array}{c}\text { Dip } \\
\left({ }^{\circ}\right)\end{array}$ & $\begin{array}{l}\text { Rake } \\
\left({ }^{\circ}\right)\end{array}$ \\
\hline 2 & 2000/10/06 13:30:17.75 & 35.274630 & 133.349837 & 9.596 & 6.6 & $8.62 \mathrm{e} 18$ & 150 & 85 & -9 \\
\hline 357 & 2000/10/06 17:59:08.80 & 35.288127 & 133.334725 & 8.414 & 3.6 & $2.47 \mathrm{e} 14$ & 345 & 84 & -10 \\
\hline 372 & 2000/10/06 18:06:25.56 & 35.313668 & 133.324959 & 8.121 & 3.4 & $1.46 \mathrm{e} 14$ & 141 & 80 & -15 \\
\hline 474 & 2000/10/06 19:19:40.32 & 35.313025 & 133.325903 & 7.196 & 3.7 & $3.59 \mathrm{e} 14$ & 162 & 85 & -4 \\
\hline 512 & 2000/10/06 19:57:22.92 & 35.269775 & 133.345939 & 12.936 & 3.5 & $1.84 \mathrm{e} 14$ & 156 & 83 & 23 \\
\hline 523 & 2000/10/06 20:04:50.56 & 35.194637 & 133.429028 & 11.342 & 3.4 & $1.26 \mathrm{e} 14$ & 136 & 90 & 6 \\
\hline 664 & $2000 / 10 / 06$ 22:56:59.72 & 35.184054 & 133.431038 & 14.123 & 4.1 & $1.35 \mathrm{e} 15$ & 128 & 76 & -38 \\
\hline 678 & $2000 / 10 / 06$ 23:13:22.12 & 35.296309 & 133.290967 & 7.462 & 4.1 & $1.84 \mathrm{e} 15$ & 253 & 71 & 177 \\
\hline 769 & 2000/10/07 03:58:16.38 & 35.328951 & 133.318091 & 9.427 & 3.5 & $2.01 \mathrm{e} 14$ & 143 & 90 & -15 \\
\hline 775 & 2000/10/07 04:50:24.78 & 35.319958 & 133.330591 & 6.940 & 3.5 & $1.78 \mathrm{e} 14$ & 174 & 79 & -21 \\
\hline 776 & 2000/10/07 04:56:03.38 & 35.250940 & 133.371712 & 9.918 & 3.8 & $5.40 \mathrm{e} 14$ & 129 & 86 & -21 \\
\hline 780 & 2000/10/07 04:59:31.14 & 35.290767 & 133.362036 & 6.773 & 4.4 & $3.78 \mathrm{e} 15$ & 50 & 51 & 125 \\
\hline 791 & 2000/10/07 05:40:38.54 & 35.377999 & 133.289429 & 8.867 & 3.5 & $2.35 \mathrm{e} 14$ & 164 & 90 & -26 \\
\hline 801 & $2000 / 10 / 07$ 06:22:35.87 & 35.310494 & 133.326904 & 7.905 & 3.8 & $5.44 \mathrm{e} 14$ & 158 & 72 & -17 \\
\hline 803 & $2000 / 10 / 07$ 06:38:11.29 & 35.357096 & 133.300269 & 8.259 & 4.3 & $3.21 \mathrm{e} 15$ & 156 & 86 & -38 \\
\hline 811 & 2000/10/07 07:24:17.86 & 35.362598 & 133.315389 & 7.625 & 3.8 & $5.80 \mathrm{e} 14$ & 340 & 80 & 41 \\
\hline 815 & 2000/10/07 07:49:30.95 & 35.269735 & 133.363957 & 12.339 & 3.9 & $7.59 \mathrm{e} 14$ & 159 & 87 & 10 \\
\hline 820 & 2000/10/07 08:17:53.33 & 35.381620 & 133.289404 & 8.140 & 4.1 & $1.58 \mathrm{e} 15$ & 169 & 80 & -4 \\
\hline 824 & $2000 / 10 / 07$ 08:30:48.76 & 35.241728 & 133.384513 & 9.492 & 3.6 & $3.19 \mathrm{e} 14$ & 313 & 87 & 11 \\
\hline 829 & 2000/10/07 08:57:10.55 & 35.297087 & 133.293221 & 6.564 & 3.4 & $1.32 \mathrm{e} 14$ & 240 & 49 & 164 \\
\hline 845 & 2000/10/07 10:26:53.96 & 35.250391 & 133.380461 & 10.394 & 3.7 & $3.49 \mathrm{e} 14$ & 128 & 90 & -21 \\
\hline 868 & 2000/10/07 11:57:18.80 & 35.259998 & 133.367196 & 10.987 & 3.2 & $6.29 \mathrm{e} 13$ & 341 & 86 & -21 \\
\hline 869 & 2000/10/07 12:03:50.96 & 35.372974 & 133.314144 & 8.860 & 4.2 & $2.31 \mathrm{e} 15$ & 335 & 82 & -14 \\
\hline 871 & 2000/10/07 12:14:23.59 & 35.315999 & 133.317326 & 7.045 & 3.3 & $1.14 \mathrm{e} 14$ & 320 & 46 & 4 \\
\hline 915 & $2000 / 10 / 07$ 16:10:38.10 & 35.361694 & 133.328687 & 7.509 & 3.7 & $3.61 \mathrm{e} 14$ & 172 & 89 & -10 \\
\hline 928 & $2000 / 10 / 07$ 17:04:31.20 & 35.372880 & 133.282137 & 8.306 & 3.7 & $3.71 \mathrm{e} 14$ & 161 & 87 & -37 \\
\hline 929 & $2000 / 10 / 07$ 17:07:55.40 & 35.358899 & 133.296867 & 9.422 & 3.3 & $1.06 \mathrm{e} 14$ & 351 & 86 & 20 \\
\hline 943 & 2000/10/07 18:32:11.74 & 35.313123 & 133.323356 & 8.083 & 3.9 & $8.80 \mathrm{e} 14$ & 146 & 71 & -40 \\
\hline 1061 & 2000/10/08 06:08:21.18 & 35.337614 & 133.296834 & 6.757 & 3.9 & $7.79 \mathrm{e} 14$ & 169 & 74 & -10 \\
\hline 1063 & 2000/10/08 06:20:58.64 & 35.223246 & 133.386914 & 7.112 & 3.4 & $1.49 \mathrm{e} 14$ & 175 & 47 & 19 \\
\hline 1132 & $2000 / 10 / 08$ 13:17:55.45 & 35.138822 & 133.152531 & 5.250 & 5.1 & $4.65 \mathrm{e} 16$ & 150 & 86 & -11 \\
\hline 1162 & $2000 / 10 / 08$ 15:47:35.57 & 35.360539 & 133.291341 & 8.915 & 3.7 & $3.80 \mathrm{e} 14$ & 158 & 83 & -56 \\
\hline 1186 & 2000/10/08 18:19:42.08 & 35.315120 & 133.320540 & 7.676 & 3.4 & $1.32 \mathrm{e} 14$ & 171 & 70 & -2 \\
\hline 1207 & 2000/10/08 20:51:17.08 & 35.363224 & 133.316536 & 8.224 & 5.0 & $3.11 \mathrm{e} 16$ & 165 & 87 & -9 \\
\hline 1212 & 2000/10/08 20:59:36.60 & 35.364335 & 133.308016 & 7.741 & 4.0 & $1.06 \mathrm{e} 15$ & 175 & 70 & 18 \\
\hline 1218 & 2000/10/08 21:33:59.00 & 35.351880 & 133.323104 & 6.353 & 3.4 & $1.61 \mathrm{e} 14$ & 170 & 69 & 53 \\
\hline 1308 & $2000 / 10 / 09$ 06:59:26.13 & 35.317521 & 133.311564 & 6.576 & 3.3 & $9.02 \mathrm{e} 13$ & 330 & 80 & -5 \\
\hline 1433 & 2000/10/09 19:24:05.36 & 35.270280 & 133.350741 & 11.511 & 3.3 & $9.06 \mathrm{e} 13$ & 123 & 57 & -18 \\
\hline 1438 & $2000 / 10 / 09$ 19:49:57.76 & 35.315649 & 133.318254 & 6.723 & 3.2 & $6.18 \mathrm{e} 13$ & 149 & 83 & -22 \\
\hline 1501 & 2000/10/10 02:26:16.92 & 35.315332 & 133.320247 & 6.661 & 3.4 & $1.36 \mathrm{e} 14$ & 334 & 89 & 36 \\
\hline 1522 & 2000/10/10 04:49:18.41 & 35.144991 & 133.154224 & 6.735 & 3.5 & $2.19 \mathrm{e} 14$ & 146 & 87 & -32 \\
\hline 1650 & $2000 / 10 / 10$ 17:19:48.00 & 35.363969 & 133.298665 & 10.595 & 3.4 & $1.53 \mathrm{e} 14$ & 152 & 67 & -1 \\
\hline 1664 & $2000 / 10 / 10 \quad 18: 22: 43.92$ & 35.345732 & 133.320492 & 8.652 & 3.3 & $1.01 \mathrm{e} 14$ & 146 & 85 & -3 \\
\hline 1693 & 2000/10/10 21:57:59.48 & 35.367550 & 133.310116 & 9.416 & 4.4 & $4.15 \mathrm{e} 15$ & 163 & 90 & -14 \\
\hline 1980 & 2000/10/12 03:53:31.34 & 35.363049 & 133.301009 & 8.177 & 3.8 & $5.59 \mathrm{e} 14$ & 252 & 59 & 179 \\
\hline 2017 & 2000/10/12 06:48:51.93 & 35.369495 & 133.286027 & 8.804 & 3.5 & $2.34 \mathrm{e} 14$ & 338 & 84 & 30 \\
\hline 2020 & 2000/10/12 07:09:00.38 & 35.369360 & 133.285579 & 8.482 & 3.7 & $3.62 \mathrm{e} 14$ & 147 & 85 & -26 \\
\hline 2037 & 2000/10/12 08:41:57.76 & 35.359049 & 133.303255 & 8.371 & 3.5 & $1.88 \mathrm{e} 14$ & 341 & 80 & 21 \\
\hline 2131 & 2000/10/12 17:07:36.80 & 35.333341 & 133.320028 & 9.742 & 3.7 & $3.95 \mathrm{e} 14$ & 169 & 85 & -8 \\
\hline 2179 & 2000/10/12 21:48:30.10 & 35.332837 & 133.304557 & 8.036 & 3.4 & $1.27 \mathrm{e} 14$ & 337 & 71 & 44 \\
\hline 2298 & $2000 / 10 / 13$ 10:44:22.01 & 35.270577 & 133.352417 & 9.765 & 3.3 & $1.10 \mathrm{e} 14$ & 143 & 79 & 15 \\
\hline 2493 & 2000/10/14 08:01:04.97 & 35.367114 & 133.317285 & 10.390 & 3.6 & $2.38 \mathrm{e} 14$ & 65 & 88 & -175 \\
\hline 2679 & $2000 / 10 / 14$ 23:34:44.60 & 35.325936 & 133.298934 & 6.586 & 3.4 & $1.64 \mathrm{e} 14$ & 161 & 76 & -31 \\
\hline 3288 & 2000/10/17 06:46:56.93 & 35.212944 & 133.394295 & 13.949 & 3.3 & $8.75 \mathrm{e} 13$ & 155 & 84 & 33 \\
\hline 3418 & $2000 / 10 / 17$ 19:20:30.08 & 35.362659 & 133.299406 & 8.961 & 3.4 & $1.37 \mathrm{e} 14$ & 252 & 66 & 178 \\
\hline 3447 & $2000 / 10 / 17$ 22:10:49.52 & 35.293156 & 133.298665 & 7.194 & 3.4 & $1.29 \mathrm{e} 14$ & 216 & 65 & 155 \\
\hline 3448 & 2000/10/17 22:16:59.56 & 35.189815 & 133.433577 & 12.126 & 4.3 & $2.84 \mathrm{e} 15$ & 309 & 87 & 18 \\
\hline 3483 & 2000/10/18 01:54:29.15 & 35.185661 & 133.431641 & 18.239 & 3.3 & $1.10 \mathrm{e} 14$ & 129 & 76 & -18 \\
\hline 3529 & 2000/10/18 08:05:12.39 & 35.378939 & 133.302620 & 10.381 & 3.5 & $1.75 \mathrm{e} 14$ & 166 & 78 & -15 \\
\hline 3637 & $2000 / 10 / 18 \quad 23: 39: 34.00$ & 35.224577 & 133.296745 & 7.311 & 3.7 & $3.55 \mathrm{e} 14$ & 258 & 69 & -157 \\
\hline
\end{tabular}


Table 2

(Continued)

\begin{tabular}{|c|c|c|c|c|c|c|c|c|c|}
\hline Event ID & $\begin{array}{c}\text { Origin Time } \\
\text { (yyyy/mm/dd JST) }\end{array}$ & $\begin{array}{l}\text { Latitude } \\
\left({ }^{\circ} \mathrm{E}\right)\end{array}$ & $\begin{array}{l}\text { Longitude } \\
\left({ }^{\circ}\right)\end{array}$ & $\begin{array}{l}\text { Depth } \\
(\mathrm{km})\end{array}$ & $M_{\mathrm{w}}$ & $\begin{array}{c}M_{0} \\
(\mathrm{Nm})\end{array}$ & $\begin{array}{l}\text { Strike } \\
\left({ }^{\circ}\right)\end{array}$ & $\begin{array}{l}\text { Dip } \\
\left({ }^{\circ}\right)\end{array}$ & $\begin{array}{c}\text { Rake } \\
\left({ }^{\circ}\right)\end{array}$ \\
\hline 3737 & 2000/10/19 08:03:41.64 & 35.377922 & 133.273405 & 9.145 & 3.8 & $4.90 \mathrm{e} 14$ & 259 & 60 & 176 \\
\hline 4236 & 2000/10/21 07:40:38.83 & 35.384452 & 133.303548 & 10.024 & 3.4 & $1.66 \mathrm{e} 14$ & 156 & 87 & -23 \\
\hline 5030 & 2000/10/24 07:43:34.95 & 35.249040 & 133.381120 & 9.705 & 3.5 & $1.71 \mathrm{e} 14$ & 132 & 71 & -44 \\
\hline 5271 & 2000/10/25 08:03:04.46 & 35.189299 & 133.430534 & 11.818 & 3.3 & $1.07 \mathrm{e} 14$ & 123 & 81 & -31 \\
\hline 5996 & 2000/10/28 20:08:22.88 & 35.280664 & 133.348812 & 7.536 & 3.2 & $7.70 \mathrm{e} 13$ & 202 & 49 & 82 \\
\hline 6450 & 2000/10/30 15:58:44.86 & 35.190686 & 133.433073 & 11.372 & 3.4 & $1.38 \mathrm{e} 14$ & 311 & 81 & 18 \\
\hline 6958 & 2000/11/03 09:40:54.78 & 35.359652 & 133.294946 & 8.427 & 3.8 & $5.26 \mathrm{e} 14$ & 165 & 89 & 85 \\
\hline 6972 & 2000/11/03 12:37:33.92 & 35.447888 & 133.253963 & 12.159 & 3.4 & $1.22 \mathrm{e} 14$ & 287 & 87 & -17 \\
\hline 7011 & $2000 / 11 / 03 \quad 16: 33: 54.86$ & 35.356299 & 133.296818 & 8.759 & 4.4 & $5.23 \mathrm{e} 15$ & 165 & 84 & -3 \\
\hline 7024 & 2000/11/03 16:53:42.74 & 35.357943 & 133.297534 & 8.850 & 3.5 & $1.70 \mathrm{e} 14$ & 166 & 88 & -9 \\
\hline 7123 & 2000/11/03 20:20:41.52 & 35.349093 & 133.302832 & 7.737 & 3.2 & $7.02 \mathrm{e} 13$ & 357 & 78 & -16 \\
\hline 7209 & 2000/11/04 04:29:39.67 & 35.377873 & 133.293050 & 8.974 & 3.3 & $1.16 \mathrm{e} 14$ & 202 & 62 & 22 \\
\hline 7224 & 2000/11/04 07:15:46.86 & 35.353459 & 133.318498 & 7.280 & 3.7 & $3.58 \mathrm{e} 14$ & 180 & 68 & 19 \\
\hline 7248 & 2000/11/04 10:48:02.25 & 35.353955 & 133.305843 & 7.964 & 3.5 & $1.80 \mathrm{e} 14$ & 190 & 63 & 14 \\
\hline 7405 & 2000/11/05 03:00:31.96 & 35.190544 & 133.430835 & 11.490 & 3.6 & $3.11 \mathrm{e} 14$ & 318 & 86 & 22 \\
\hline 8469 & 2000/11/12 19:38:03.08 & 35.167371 & 133.135661 & 6.693 & 3.4 & $1.44 \mathrm{e} 14$ & 162 & 67 & -7 \\
\hline 8573 & 2000/11/13 18:32:25.02 & 35.365865 & 133.294784 & 9.064 & 3.5 & $2.31 \mathrm{e} 14$ & 348 & 86 & 15 \\
\hline
\end{tabular}

The fault plane is chosen by comparing with the aftershock trend.

Table 3

Discrete Fault Planes Obtained from the Relocated Aftershocks and Fault Mechanism Solutions

\begin{tabular}{|c|c|c|c|c|c|c|c|c|c|c|}
\hline $\begin{array}{l}\text { Fault } \\
\text { No. }\end{array}$ & $\begin{array}{c}\text { Lon1 } \\
\left({ }^{\circ} \mathrm{E}\right)\end{array}$ & $\begin{array}{l}\text { Lat1 } \\
\left({ }^{\circ} \mathrm{N}\right)\end{array}$ & $\begin{array}{c}\text { Lon2 } \\
\left({ }^{\circ} \mathrm{E}\right)\end{array}$ & $\begin{array}{l}\text { Lat2 } \\
\left({ }^{\circ} \mathrm{N}\right)\end{array}$ & $\begin{array}{c}\text { Length } \\
(\mathrm{km})\end{array}$ & $\begin{array}{l}\text { Top } \\
(\mathrm{km})\end{array}$ & $\begin{array}{c}\text { Bottom } \\
(\mathrm{km})\end{array}$ & $\begin{array}{l}\text { Strike } \\
\left({ }^{\circ}\right)\end{array}$ & $\begin{array}{c}\text { Dip } \\
\left(^{\circ}\right)\end{array}$ & $\begin{array}{c}\text { Rake* } \\
\left({ }^{\circ}\right)\end{array}$ \\
\hline 1 & 133.381036 & 35.243979 & 133.436638 & 35.176345 & 9.1 & 6 & 15 & 146 & 76 & -20 \\
\hline 2 & 133.322846 & 35.304886 & 133.381036 & 35.243979 & 8.6 & 1 & 15 & 142 & 90 & 10 \\
\hline 3 & 133.340950 & 35.309134 & 133.281466 & 35.295325 & 5.7 & 4 & 10 & 74 & 87 & -170 \\
\hline 4 & 133.312931 & 35.334631 & 133.331035 & 35.309134 & 3.3 & 4 & 16 & 150 & 90 & -10 \\
\hline 5 & 133.278450 & 35.377479 & 133.306465 & 35.345255 & 4.4 & 7 & 10 & 144 & 90 & -20 \\
\hline 6 & 133.296983 & 35.365792 & 133.312070 & 35.348796 & 2.3 & 7 & 9 & 144 & 90 & -20 \\
\hline 9 & 133.312070 & 35.380665 & 133.321120 & 35.350567 & 3.5 & 6 & 9 & 166 & 90 & -10 \\
\hline 10 & 133.337068 & 35.377831 & 133.296550 & 35.357647 & 4.3 & 7 & 11 & 59 & 86 & 180 \\
\hline 11 & 133.303881 & 35.381728 & 133.348274 & 35.376061 & 4.1 & 7 & 10 & 99 & 90 & - \\
\hline 12 & 133.322414 & 35.379957 & 133.331464 & 35.359417 & 2.4 & 7 & 10 & 160 & 90 & -10 \\
\hline 13 & 133.299138 & 35.396246 & 133.308188 & 35.363314 & 3.8 & 8 & 11 & 167 & 90 & -10 \\
\hline 20 & 133.252586 & 35.448299 & 133.259913 & 35.446884 & 0.7 & 11 & 12 & 103 & 90 & 20 \\
\hline 22 & 133.150000 & 35.143413 & 133.159915 & 35.126415 & 2.1 & 4 & 7 & 334 & 86 & 10 \\
\hline 23 & 133.134912 & 35.158639 & 133.154310 & 35.145536 & 2.3 & 5 & 8 & 129 & 90 & -10 \\
\hline 24 & 133.123274 & 35.179179 & 133.139656 & 35.159349 & 2.7 & 5 & 8 & 326 & 85 & - \\
\hline
\end{tabular}

*In faults 11 and 24, rake angles could not be estimated because their fault planes were very clearly recognized, but no moment tensor solutions were estimated on these faults.

although 11 is not estimated the slip direction from moment tensor analysis, the principal stress direction becomes $\mathrm{N} 130^{\circ} \mathrm{E}$, which is consistent with the first solution (North 1) for the northern part.

Background seismicity along the aftershock region was recognized before the mainshock (Shibutani et al., 2002). In the southern part, the same lineament was observed by the background seismicity, which suggests the pre-existed fault plane in the southern part. On the other hand, in the northern part, the background seismicity was vague and the preexisting fault trace was not well developed before the mainshock.

Thus in the North 2 case, the background stress field is considered to be homogeneous and the difference in fault orientations in the northern and southern parts is attributed to the variation of the friction on the fault. In North 1, on the other hand, the background stress field might be heterogeneous in the northern part, but the friction on the fault is rather homogeneous. As discussed in Rivera and Kanamori (2002), we could not resolve these two possibilities from the observation and additional information might be necessary.

\section{Discussion}

It should be noted that the complex pattern of aftershocks obtained in the present analysis can largely be ex- 


\section{Fault Model of the 2000 Western Tottori Earthquake Sequence}

(a) Plane View with aftershocks

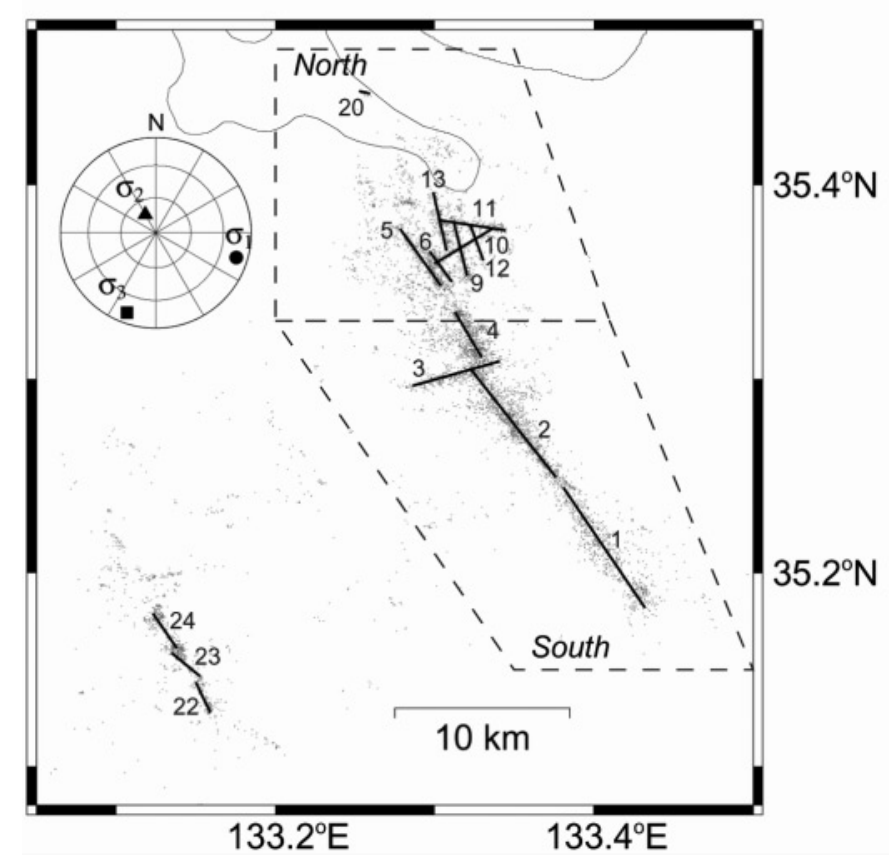

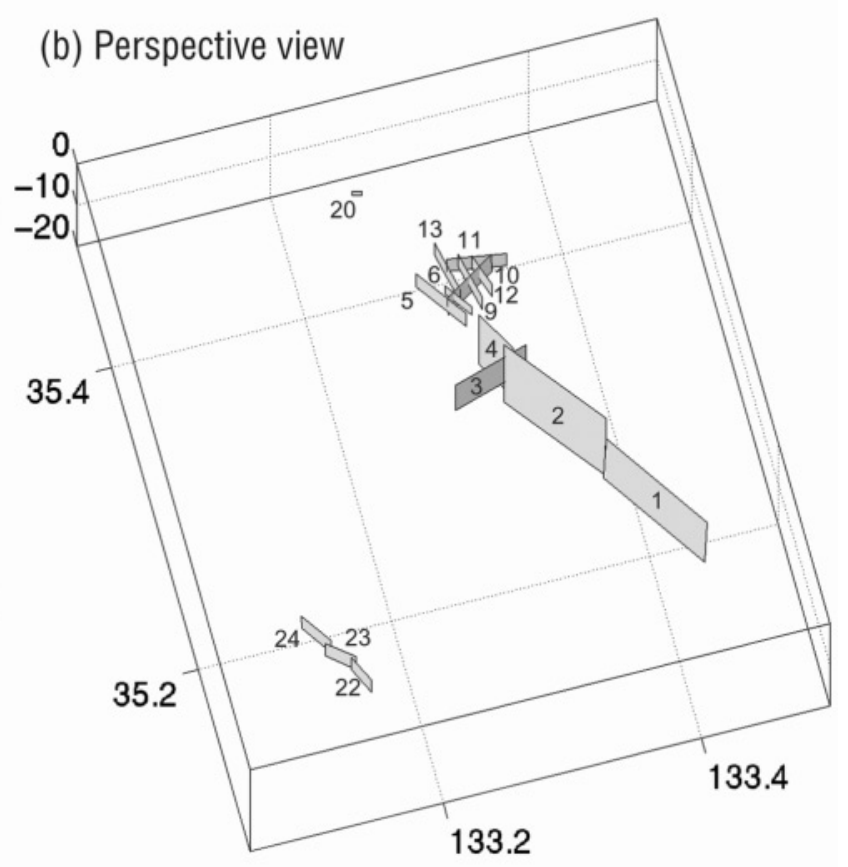

Figure 6. Fault model of the 2000 western Tottori earthquake. (a) Map view with relocated aftershocks. (b) Perspective view of inferred fault orientations. The areas named North and South surrounded by dotted lines correspond to the subset regions for the stress tensor inversion shown in Figure 7.

plained by a finite set of faults displaying brittle deformation. All the structures that can be seen from the hypocenter distribution are also consistent with the corresponding moment tensor solutions.

In the southern part, where the rupture occurred during the mainshock (Yagi and Kikuchi, 2000; Iwata and Sekiguchi, 2001), the shape of the fault is rather simple. But at the southern end, the fault is slightly twisted (Fig. 2). This might be due to the effect of the dynamic rupture. Due to the vertical gradient of the velocity structure in this region, the relative rupture velocity with respect to the shear-wave velocity becomes different between shallow and deep portions of the fault. This causes the variation of hoop stress distribution (Freund, 1990) along depth.

In the northern part, on the other hand, the fault zone appeared just after the mainshock. From the GPS measurement, most of the postseismic slip occurred in this region (Sagiya et al., 2002). This suggests that in the northern part, ductile slip started to occur just after the mainshock, and aftershocks might be caused by the stress change due to this postseismic slip. A similar phenomenon has been found in the subduction zone where postseismic slip were observed around the mainshock slip area (Yagi et al., 2001). Moreover, in the northern part, there is a possibility that the stress field might be rotated slightly clockwise. This rotation might be caused by the postseismic slip detected by the GPS observation.

\section{Conclusion}

We relocated the aftershocks of the $M_{\mathrm{w}} 6.62000$ western Tottori earthquake using the DD method and obtained a very accurate hypocenter distribution. By combining the relocated hypocenters and moment tensor solutions of aftershocks by broadband waveform inversion, we successfully resolved very detailed fault structures activated by the mainshock. The estimated fault model resolves 15 individual fault segments that are consistent with both aftershock distribution and focal mechanism solutions. Most of the faults are left-lateral strike-slip faults. We found that there are two predominant directions for left-lateral faulting striking $\mathrm{N} 145^{\circ} \mathrm{E}$ and $\mathrm{N} 165^{\circ} \mathrm{E}$. Conjugate right-lateral faults are paired with both sets of left-lateral faults.

Rupture in the mainshock was principally confined to the three fault elements in the southern half of the zone, which is also where the earliest aftershocks concentrate. With time, the northern part of the zone becomes activated, which is also reflected in the postseismic deformation field determined by Sagiya et al. (2002). We conducted stress tensor inversion of aftershock focal mechanisms and found 
(a) ALL
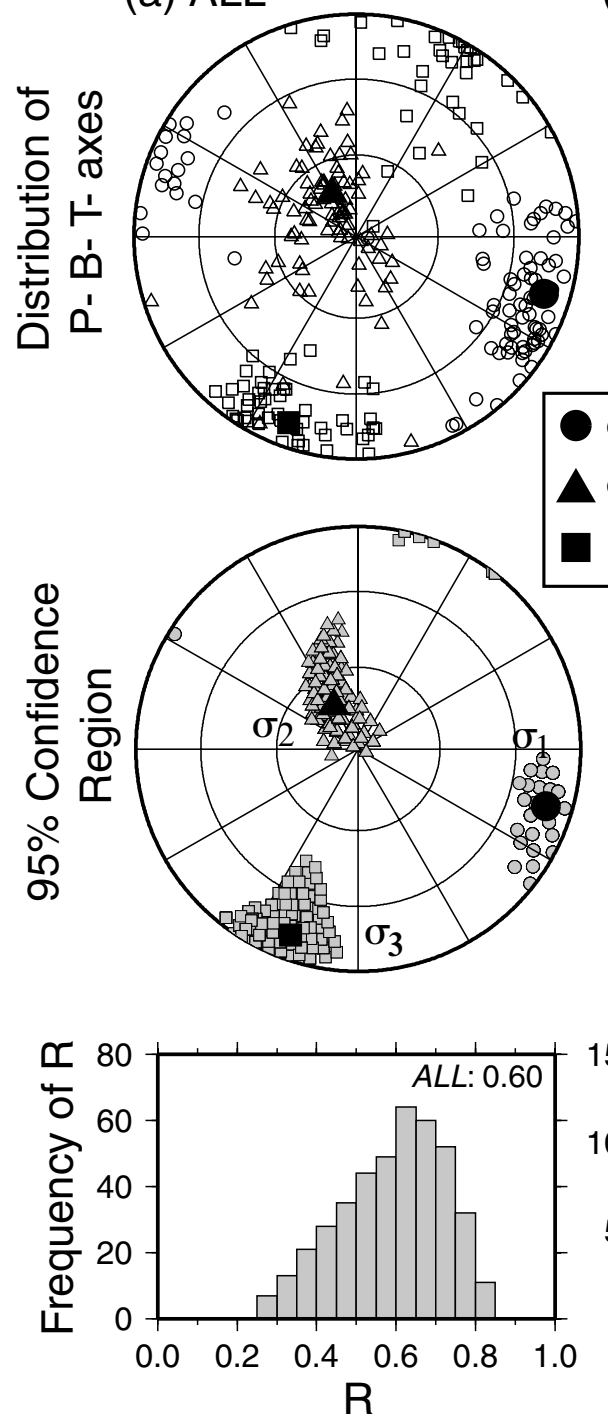

(b) North
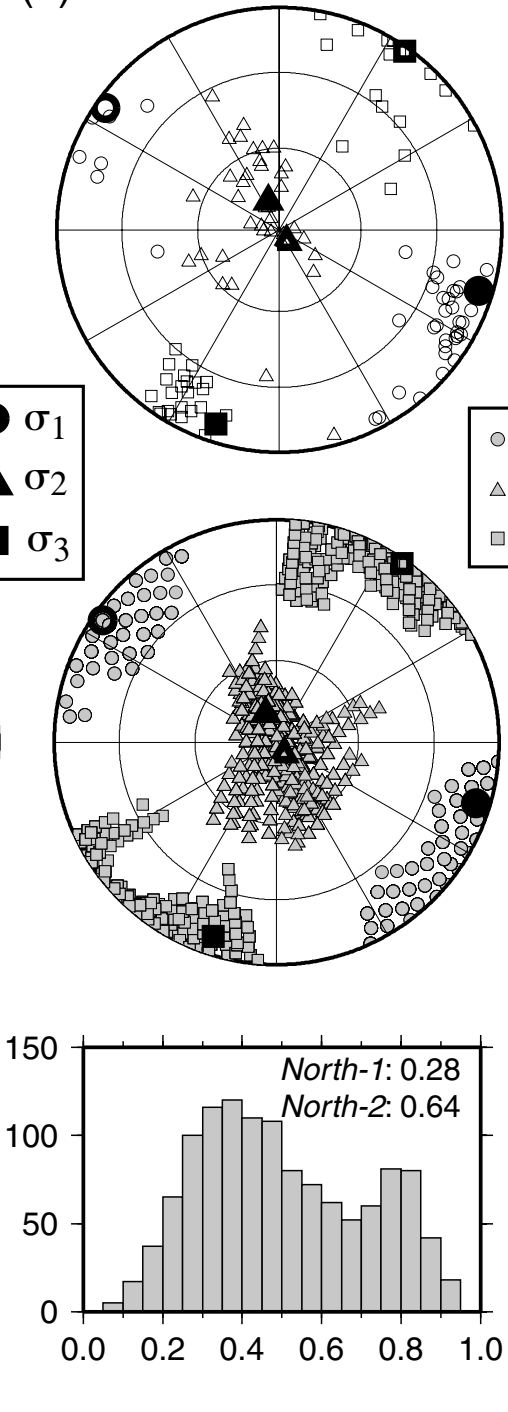

(c) South
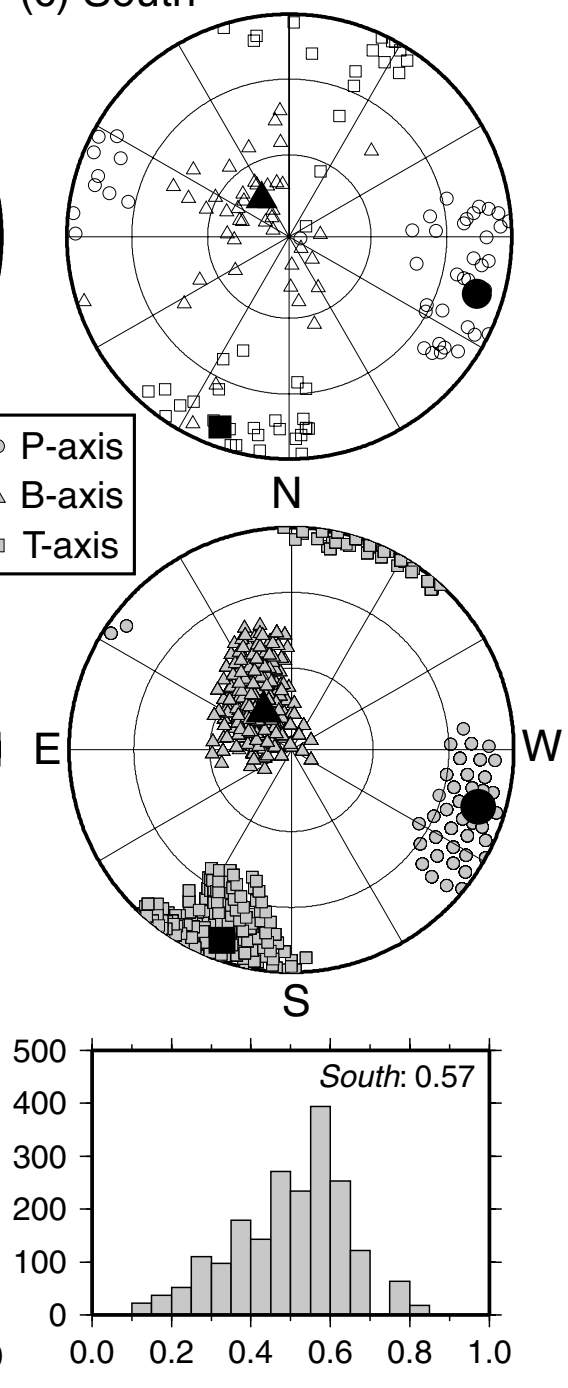

Figure 7. Result of stress tensor inversion: (a) ALL, (b) North 1 and North 2, and (c) South. Upper row shows the distribution of $P$ - (gray circle), $B$ - (gray triangle) and $T$-axes (gray square) and obtained stress axes $\left(\sigma_{1}\right.$, solid circle; $\sigma_{2}$, solid triangle; and $\sigma_{3}$, solid square). Middle row shows the $95 \%$ confidence region of the stress tensor inversion. Bottom row shows the frequency distribution of $R$, which belongs to the $95 \%$ confidence region. In the North column, two solutions are displayed simultaneously. Solid symbols are for the North 1 solution and open symbols are for the North 2 solution, respectively.

Table 4

Result of Stress Tensor Inversion

\begin{tabular}{lcccccccc}
\hline Region & $\begin{array}{c}\sigma_{1} \text { Plunge } \\
\left({ }^{\circ}\right.\end{array}$ & $\begin{array}{c}\sigma_{1} \text { Azimuth } \\
\left({ }^{\circ}\right)\end{array}$ & $\begin{array}{c}\sigma_{2} \text { Plunge } \\
\left({ }^{\circ}\right)\end{array}$ & $\begin{array}{c}\sigma_{2} \text { Azimuth } \\
\left({ }^{\circ}\right)\end{array}$ & $\begin{array}{c}\sigma_{3} \text { Plunge } \\
\left({ }^{\circ}\right)\end{array}$ & $\begin{array}{r}\sigma_{3} \text { Azimuth } \\
\left({ }^{\circ}\right)\end{array}$ & $\begin{array}{c}\text { Residual } \\
\left({ }^{\circ}\right)\end{array}$ \\
\hline ALL & 13 & 107 & 72 & 303 & 12 & 200 & 0.60 & 4.868 \\
North 1 & 7 & 308 & 83 & 146 & 2 & 38 & 0.28 & 4.223 \\
North 2 & 7 & 107 & 79 & 339 & 9 & 198 & 0.64 & 4.283 \\
South & 13 & 107 & 73 & 324 & 10 & 200 & 0.57 & 4.739 \\
\hline
\end{tabular}


that the maximum stress direction obtained from the stress tensor inversion is $\mathrm{N} 107^{\circ} \mathrm{E}$, which is consistent with other estimates of the tectonic stress field in this region. Slip on the complex fault network in the northern part can be explained either by the stress field responsible for the mainshock or by a $20^{\circ}$ clockwise rotation of the stress field.

\section{Acknowledgments}

We would like to thank the Japan Meteorological Agency for providing us all the phase reading data for the western Tottori sequence. Reviews by Jeanne Hardebeck, associate editor, and Björn Lund and Judith Sheridan were valuable in improving the manuscript. Comments by David Schaff were helpful. GMT - the Generic Mapping Tools data processing and display software package - was used to make the figures. This work was conducted under the project "Fundamental Research on Earthquake Source and Earth Anomaly" and "Research on Earthquake Mechanism" at the National Research Institute for Earth Science and Disaster Prevention.

\section{References}

Centroid Moment Tensor Catalog. www.seismology.harvard.edu/CMT search.html.

Fukuyama, E., and D. S. Dreger (2000). Performance test for automated moment tensor determination system by using synthetic waveforms of the future Tokai earthquake, Earth Planets Space 52, 383-392.

Fukuyama, E., M. Ishida, D. S. Dreger, and H. Kawai (1998). Automated seismic moment tensor determination by using on-line broadband seismic waveforms, Zisin (J. Seismol. Soc. Jpn.) Ser. 2, 51, 149-156 (in Japanese with English abstract).

Fukuyama, E., M. Ishida, S. Horiuchi, H. Inoue, S. Hori, S. Sekiguchi, T. Eguchi, A. Kubo, H. Kawai, H. Murakami, S. Yamamoto, and K. Nonomura (2001a). NIED seismic moment tensor catalogue JanuaryDecember, 2000, Technical Notes of the National Research Institute for Earth Science and Disaster Prevention 217, 1-131.

Fukuyama, E., A. Kubo, H. Kawai, and K. Nonomura (2001b). Seismic remote monitoring of stress field, Earth Planets Space 53, 1021-1026.

Freund, L. B. (1990). Dynamic Fracture Mechanics, Cambridge U Press, New York, 563 pp.

Gephart, J. W. (1990a). Stress and the direction of slip on fault planes, Tectonics 9, 845-858.

Gephart, J. W. (1990b). FMSI: a Fortran program for inverting fault/slickenside and earthquake focal mechanism data to obtain the regional stress tensor, Comput. Geosci. 16, 935-989.

Gephart, J. W., and D. W. Forsyth (1984). An improved method for determining the regional stress tensor using earthquake focal mechanism data: application to the San Fernando earthquake sequence, J. Geophys. Res. 89, 9305-9320.

Ichikawa, M. (1971). Reanalyses of mechanism of earthquakes which occurred in and near Japan and statistical studies on the nodal plane solutions obtained 1926-1968, Geophys. Mag. 35, 207-274.

Iwata, T., and H. Sekiguchi (2001). Substance of the earthquake faulting during the 2000 western Tottori earthquake, SEISMO 5, March 2001, 5-7 (in Japanese).
Japan Meteorological Agency (2001). The Seismological and Volcanological Bulletin of Japan, Japan Meteorological Agency, Tokyo.

Joint Group for Dense Aftershock Observation of the 2000 Tottori-ken Seibu Earthquake (2001). Aftershock distribution of the 2000 Tottoriken Seibu earthquake determined precisely by dense aftershock observation, Abstracts 2001 Japan Earth and Plantary Science Joint Meeting, S3-005, Tokyo, 4-8 June (CD-Rom).

Kanamori, H. (1972). Determination of effective tectonic stress associated with earthquake faulting, the Tottori earthquake of 1943, Phys. Earth Planet. Interiors, 5, 426-434.

Kubo, A., E. Fukuyama, H. Kawai, and K. Nonomura (2002). NIED seismic moment tensor catalogue for regional earthquakes around Japan: quality test and application, Tectonophysics 356, 23-48.

NIED Seismic Moment Tensor Catalog, www.fnet.bosai.go.jp.

Research Group for Active Faults of Japan (1991). Active Faults in Japan, (New Edition), Tokyo University Press, Tokyo (in Japanese).

Rivera, L., and H. Kanamori (2002). Spatial heterogeneity of tectonic stress and friction in the crust, Geophys. Res. Lett. 29, no. 6, 1088, doi 10.1029/2001GL013803.

Sagiya, T., T. Nishimura, Y. Hatanaka, E. Fukuyama, and W. L. Ellsworth (2002). Crustal movements associate with the 2000 western Tottori earthquake and its fault models, Zisin (J. Seismol. Soc. Jpn.) Ser. 54, 523-534 (in Japanese with English abstract).

Shibutani, T., S. Nakao, R. Nishida, F. Takeuchi, K. Watanabe, and Y. Umeda (2002). Swarm-like seismic activity in 1989, 1990, and 1997 preceding the 2000 western Tottori earthquake, Earth Planets Space 54, 831-845.

Tsukahara, H., and Y. Kobayashi (1991). Crustal stress in the central and western parts of Honshu, Japan, Zisin (J. Seismol. Soc. Jpn.) Ser. 2, 44, 221-231 (in Japanese with English abstract).

Waldhauser, F., and W. L. Ellsworth (2000). A double-difference earthquake location algorithm: method and application to the northern Hayward fault, California, Bull. Seism. Soc. Am. 90, 1353-1368.

Yagi, Y., and M. Kikuchi (2000). Source process of the 2000 October 6 western Tottori earthquake (preliminary report), Newslett. Seism. Soc. Jpn. 12, no. 4, 9-10 (in Japanese).

Yagi, Y., M. Kikuchi, and T. Sagiya (2001). Co-seismic slip, post-seismic slip, and aftershocks associated with two large earthquakes in 1996 in Hyuga-nada, Japan, Earth Planets Space 53, 793-803.

National Research Institute for Earth Science and Disaster Prevention 3-1 Tennodai, Tsukuba, Ibaraki, 305-0006 Japan

fuku@ bosai.go.jp

kubo@bosai.go.jp

(E.F., A.K.)

U.S. Geological Survey

345 Middlefield Road, Menlo Park, California 94025

ellsworth@usgs.gov

(W.L.E., F.W.)

now at Lamont-Doherty Earth Observatory

Columbia University

61 Route 9W, Palisades, New York 10964

felixw@1deo.columbia.edu

(F.W.)

Manuscript received 21 May 2002. 